\title{
Single Granule Cells Excite Golgi Cells and Evoke Feedback Inhibition in the Cochlear Nucleus
}

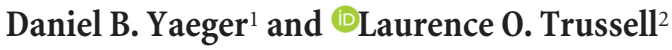 \\ ${ }^{1}$ Department of Physiology and Pharmacology, Oregon Health and Science University, Portland, Oregon 97239, and ${ }^{2}$ Vollum Institute and Oregon Hearing \\ Research Center, Oregon Health and Science University, Portland, Oregon 97239
}

In cerebellum-like circuits, synapses from thousands of granule cells converge onto principal cells. This fact, combined with theoretical considerations, has led to the concept that granule cells encode afferent input as a population and that spiking in individual granule cells is relatively unimportant. However, granule cells also provide excitatory input to Golgi cells, each of which provide inhibition to hundreds of granule cells. We investigated whether spiking in individual granule cells could recruit Golgi cells and thereby trigger widespread inhibition in slices of mouse cochlear nucleus. Using paired whole-cell patch-clamp recordings, trains of action potentials at $100 \mathrm{~Hz}$ in single granule cells was sufficient to evoke spikes in Golgi cells in $\sim 40 \%$ of paired granule-to-Golgi cell recordings. High-frequency spiking in single granule cells evoked IPSCs in $\sim 5 \%$ of neighboring granule cells, indicating that bursts of activity in single granule cells can recruit feedback inhibition from Golgi cells. Moreover, IPSPs mediated by single Golgi cell action potentials paused granule cell firing, suggesting that inhibitory events recruited by activity in single granule cells were able to control granule cell firing. These results suggest a previously unappreciated relationship between population coding and bursting in single granule cells by which spiking in a small number of granule cells may have an impact on the activity of a much larger number of granule cells.

Key words: auditory; cerebellum; inhibition; microcircuits

\section{Introduction}

Cerebellar cortex and cerebellum-like circuits contain an abundance of granule cells. Granule cells make excitatory synapses onto principal cells in these circuits that are too weak to individually impact principal cell firing (Barbour, 1993; Brunel et al., 2004; Roberts and Trussell, 2010). Furthermore, theoretical studies emphasizing the role of principal cells as pattern learning devices highlight the importance of population coding by granule cells (Marr, 1969; Albus, 1971; Liu and Regehr, 2014). For these reasons, granule cells are typically thought to encode mossy fiber input as a population, with individual granule cells being dispensable for the overall function of the circuit (Arenz et al., 2009; Galliano et al., 2013b). However, granule cells make excitatory synapses with Golgi cells, inhibitory interneurons that feedback onto granule cells (Dugué et al., 2005; Balakrishnan et al., 2009). Golgi cells also receive excitatory input from mossy fibers (Kanichay and Silver, 2008; Cesana et al., 2013; see Fig. $1 \mathrm{~A}$ for

\footnotetext{
Received Sept. 2, 2014; revised Feb. 6, 2015; accepted Feb. 11, 2015

Author contributions: D.B.Y. and L.O.T. designed research; D.B.Y. performed research; D.B.Y. analyzed data; D.B.Y. and L.O.T. wrote the paper.

This work was funded by the National Institutes of Health (Grant DC004450 to L.0.T., Grant F31DC013223 to D.B.Y., Grant P30DC005983 to Peter Barr-Gillespie, PI, and Grant P30 NS061800 to Sue Aicher, PI), a Vertex Graduate Student Scholarship (D.B.Y.), and an Achievement Rewards for College Scientists scholarship (D.B.Y.). We thank Patrick Roberts, Paul Manis, and Stephen David for advice on simulations and data fitting; Robert Duvoisin and Louis F. Reichardt for donations of the IG17 and $\mathrm{GABA}_{A} \mathrm{R}-\alpha 6$-cre mice, respectively; and Hsin-Wei Lu, Paul Manis, Patrick Roberts, and Gabe Murphy for critical reading of an earlier version of this manuscript.

The authors declare no competing financial interests.

Correspondence should be addressed to Laurence 0 . Trussell, Vollum Institute and Oregon Hearing Research Center, Oregon Health and Science University, L335A Portland, Oregon 97239. E-mail: trussell@ohsu.edu.

DOI:10.1523/JNEUROSCI.3665-14.2015

Copyright $\odot 2015$ the authors $\quad 0270-6474 / 15 / 354741-10 \$ 15.00 / 0$
}

circuit diagram), but the granule-to-Golgi cell synapses are typically considered too weak to excite Golgi cells (Dieudonné, 1998; $\mathrm{Xu}$ and Edgley, 2008; Prsa et al., 2009). However, recent evidence suggests that the ascending axons of granule cells makes synapses onto Golgi cells that are nearly as strong as, and many times more numerous than, mossy fiber synapses onto Golgi cells (Cesana et al., 2013). Granule cell synapses onto Golgi cells are also known to undergo potent short-term synaptic facilitation (Beierlein et al., 2007), raising the possibility that bursts of spikes in individual granule cells may provide suprathreshold excitation to Golgi cells. Due to the divergence of Golgi cell axons to hundreds of granule cells (Eccles et al., 1967), spiking in single granule cells may evoke inhibition in a large population of granule cells.

We used paired recordings to address these questions. However, paired recordings are only feasible in brain areas where connection probabilities between cells are sufficiently high to gather an interpretable dataset. Indeed, in the relatively compact granule-Golgi cell network of the cerebellum-like regions of the mouse cochlear nucleus (Oertel and Young, 2004), we now report a Golgi-to-granule connection probability of $38 \%$ and a granule-to-Golgi connection probability of 33\%, 1.5-3 times the corresponding values reported in the cerebellum (Crowley et al., 2009; Cesana et al., 2013). In connected granule-to-Golgi cell pairs, bursts of 10 action potentials at $100 \mathrm{~Hz}$ evoked long-latency Golgi cell action potentials in $\sim 40 \%$ of granule-to-Golgi pairs. To test whether spiking in granule cells could evoke IPSCs, a burst of spikes was evoked in one granule cell, which resulted in IPSCs in the same cell or in a simultaneously recorded granule cell in $5-6 \%$ of recordings. Paired Golgi-to-granule recordings showed that single unitary IPSPs could pause granule cell firing. Compu- 
tational modeling suggested that the duration of inhibition of granule cell spiking increased with the number of bursting granule cells. Together, these results suggest that spiking of individual granule cells can recruit Golgi cells to deliver inhibition to a large number of granule cells.

\section{Materials and Methods}

Animals. Postnatal day 16 (P16)-P24 wild-type (C57bl/6) or IG17 homozygous or heterozygous transgenic mice were used for electrophysiological experiments. The IG17 line expresses GFP fused to the human interleukin-2 receptor $\alpha$ subunit under control of the promoter for metabotropic glutamate receptor subtype 2 (mGluR2) gene (Watanabe et al., 1998; Watanabe and Nakanishi, 2003). Golgi cells are the only inhibitory cell type in cochlear nucleus expressing GFP in IG17 mice (Irie et al., 2006). For immunostaining (see Fig. $1 B, C$ ), $I G 17^{+/-}$mice were bred to $G A B A_{A} R-\alpha 6-C r e^{+/-}$mice (Fünfschilling and Reichardt, 2002) to generate $I G 17^{+/-} / G A B A_{A} R-\alpha 6-C r e^{+/-}$mice. Granule cells are the only cochlear nucleus cells expressing Cre recombinase in $G A B A_{A} R-\alpha 6-$

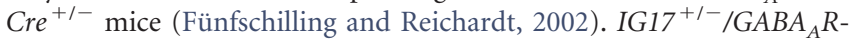
$\alpha 6-\mathrm{Cre}^{+/-}$mice were then crossed to $\mathrm{Ai}^{+/+}$mice (Madisen et al., 2010) to generate $I G 17^{+/-} / G A B A_{A} R-\alpha 6-C r e^{+/-} / A_{i 9^{+/-}}$mice. One $I G 17^{+/-} /$ $G A B A_{A} R-\alpha 6-C r e^{+/-} / A i 9^{+/-}$P24 mouse was used for immunostaining. Male or female mice were used in all experiments. All experimental procedures involving animals were approved by the Oregon Health and Science University Institutional Animal Care and Use Committee.

Immunohistochemistry. One mouse was anesthetized with isoflurane and the brain was removed after transcardial perfusion with $6.7 \mathrm{~mm}$ PBS, $\mathrm{pH} 7.4$, and subsequent perfusion with $4 \%$ paraformaldehyde in PBS $(\mathrm{w} / \mathrm{v})$. The brain was kept in $4 \%$ paraformaldehyde in PBS overnight. The brain was embedded in $4 \%$ agar in PBS (w/v) and sliced into $40 \mu \mathrm{m}$ coronal sections the following day using a vibratome (Leica VT1000S). The slices were then incubated for $1 \mathrm{~h}$ in a blocking solution consisting of $2 \%(\mathrm{w} / \mathrm{v})$ goat serum, $0.3 \%(\mathrm{w} / \mathrm{v})$ bovine serum albumin, and $0.2 \%(\mathrm{v} / \mathrm{v})$ Triton X-100 in PBS. The slices were incubated overnight in blocking solution containing Alexa Fluor 488-conjugated anti-GFP antibody (10 $\mu \mathrm{g} / \mathrm{ml}$; Invitrogen). The following day, slices were washed in PBS, mounted, and imaged using confocal microscopy.

Slice preparation. After anesthesia, mice were decapitated and coronal brain slices $(300 \mu \mathrm{m})$ containing cochlear nucleus were cut in either warm $\left(34^{\circ} \mathrm{C}\right)$ standard artificial CSF (ACSF) or K-gluconate-based solution (Dugué et al., 2005; Dugué et al., 2009). Standard ACSF contained the following (in mM): $130 \mathrm{NaCl}, 2.1 \mathrm{KCl}, 1.2 \mathrm{KH}_{2} \mathrm{PO}_{4}, 3-6$ HEPES, 1 $\mathrm{MgSO}_{4}, 1.7 \mathrm{CaCl}_{2}, 10$ glucose, and $20 \mathrm{NaHCO}_{3}$ (bubbled with $95 \%$ $\mathrm{O}_{2} / 5 \% \mathrm{CO}_{2} ; \sim 305$ mosm). The K-gluconate cutting solution contained the following (in mM): $130 \mathrm{~K}$-gluconate, $15 \mathrm{KCl}, 0.5-2$ EGTA, $20 \mathrm{HEPES}$, and 25 glucose, $\sim 320 \mathrm{mOsm}$, and $\mathrm{pH}$ adjusted to 7.4 with $\mathrm{NaOH}$. Two to $5 \mu \mathrm{M} 3$ - $[(R)$-2-carboxypiperazin-4-yl]-propyl-1-phosphonic acid [(R)$\mathrm{CPP}]$ and/or 50 nм minocycline was routinely added to cutting solutions to increase slice viability (Rousseau et al., 2012). Slices were incubated in $34^{\circ} \mathrm{C}$ ACSF for 15-30 min after slicing and then stored at room temperature until recording. All recordings were performed in the standard ACSF solution.

Electrophysiological recording. Slices were transferred to a recording chamber on the stage of an upright microscope (Zeiss Examiner.D1) and perfused continuously with ACSF using a peristaltic pump (Gilson Minipulse 3 ). Bath temperature was maintained at $34-36^{\circ} \mathrm{C}$ by an inline heater (Warner Instrument TC-324B). Cells were visualized with a $40 \times$ objective lens with Dodt gradient contrast optics using a Sony XC-ST30 infrared camera. GFP-positive cells were visualized using epiflourescence optics and a custom-built LED excitation source.

Current and voltage-clamp recordings were made with a K-gluconatebased internal solution containing the following (in $\mathrm{mM}$ ): 113 K-gluconate, $2.75 \mathrm{MgCl}_{2}, 1.75 \mathrm{MgSO}_{4}$, 9 HEPES, 0.1 EGTA, $14 \mathrm{Tris}_{2}$ phosphocreatine, $4 \mathrm{Na}_{2}$-ATP, 0.3 Tris-GTP, osmolarity adjusted to $\sim 295 \mathrm{mOsm}$ with sucrose and $\mathrm{pH}$ adjusted to 7.25 with $\mathrm{KOH}$. All reported membrane values recorded with the K-gluconate-based internal solution were corrected offline for a $-10 \mathrm{mV}$ junction potential. In Figure 5, E and F, a KCl-based solution was made by exchanging the
$\mathrm{K}$-gluconate for $\mathrm{KCl}$ and used to record from granule cells. For IV curves (see Fig. $2 B, C$ ) and extracellular stimulation of Golgi axons (see Fig. $3 F$ ), voltage-clamp recordings were made with a $\mathrm{CsCl}$-based internal solution composed of the following (in mM): $115 \mathrm{CsCl}, 4.5 \mathrm{MgCl}_{2}, 8 \mathrm{QX}-314-\mathrm{Cl}$, 10 HEPES, 10 EGTA, $4 \mathrm{Na}_{2}$-ATP, and 0.5 Tris-GTP, osmolarity $\sim 295$ $\mathrm{mOsm}$ and $\mathrm{pH}$ adjusted to 7.25 with $\mathrm{CsOH}$. The CsCl-based internal solution had a small junction potential $(\sim 2 \mathrm{mV})$ for which no correction was made. Spermine $(100 \mu \mathrm{M})$ was added to the $\mathrm{CsCl}$-based internal for some experiments (see Fig. $2 \mathrm{~B}, \mathrm{C}$ ). Patch pipettes were pulled from borosilicate glass (WPI) and open-tip resistances were 3-6 M $\Omega$ when filled with internal solution when recording from Golgi cells and 5-11 $\mathrm{M} \Omega$ when recording from granule cells.

Data acquisition and analysis. Single and dual whole-cell patch-clamp recordings were made using a MultiClamp 700B amplifier using Clampex 9.2 (Molecular Devices). Granule cells were identified based on their small soma size $(\leq 10 \mu \mathrm{m})$, characteristic intrinsic properties (Balakrishnan and Trussell, 2008), and lack of GFP expression when using IG17 mice. Golgi cells were identified based upon their GFP expression in IG17 mice, multipolar appearance, medium- to large-sized somas ( $\geq 15 \mu \mathrm{m})$, and intrinsic properties (Irie et al., 2006). Whole-cell access resistance was 6-25 $\mathrm{M} \Omega$ in voltage-clamp recordings from Golgi cells and 12-35 $\mathrm{M} \Omega$ in voltage-clamp recordings from granule cells. Access resistance was compensated by $70 \%$ online. Recordings were acquired at $10-50$ $\mathrm{kHz}$ and low-passed filtered at $10 \mathrm{kHz}$ using a Digidata 1322A (Molecular Devices).

For paired recordings in which the presynaptic cell was recorded in current clamp, action potentials were evoked in Golgi cells with a $1 \mathrm{~ms}$, $1.2-1.8 \mathrm{nA}$ current injection and in granule cells with a $1 \mathrm{~ms}, 0.6-0.9 \mathrm{nA}$ current injection. In experiments determining whether single granule cells could evoke Golgi cell spikes in granule-Golgi cell pairs (see Fig. $5 A, B)$, postsynaptic Golgi cells were held to potentials slightly hyperpolarized to the resting potential $(-75.2 \pm 1.0 \mathrm{mV}, n=17)$ to prevent spontaneous firing because the resting membrane potential of Golgi cells tended to gradually depolarize during prolonged whole-cell recordings (data not shown). When recording postsynaptic currents, Golgi cells were held at -60 to $-70 \mathrm{mV}$ and granule cells were held at either -40 or $0 \mathrm{mV}$. In single voltage-clamp recordings from granule cells examining feedback inhibition (see Fig. $5 E, F$ ), action currents were evoked by a 1 $\mathrm{ms}$ depolarization to $0 \mathrm{mV}$ from a holding potential of -60 to $-70 \mathrm{mV}$.

In analyzing kinetic data from postsynaptic events in paired recordings, postsynaptic events were aligned at onset using Axograph X and averaged. When analyzing the kinetics of EPSCs in paired recordings between granule and Golgi cells, the EPSC in response to the first granule cell action potential was analyzed whenever possible to avoid changes in EPSC kinetics related to short-term synaptic plasticity at granule cell synapses (Satake and Imoto, 2014). Synaptic latency was calculated by taking the difference between the time of the averaged peak of the presynaptic action potential and the time of the peak of the first derivative of the postsynaptic current (Crowley et al., 2009). EPSCs and IPSCs were fitted with either a monoexponential or biexponential decay function in Clampfit (Molecular Devices) as follows:

$$
A_{\text {fast }} \times e^{\frac{-T}{\tau_{\text {fast }}}}+A_{\text {slow }} \times e^{\frac{-T}{\tau_{\text {slow }}}}
$$

where $T=t-t_{0}$, and $t_{0}$ is the time to which the first point of the fit corresponds. The biexponential fit was considered the best if it reduced the sum of squared errors compared with the mono-exponential fit by more than half.

Chemicals. All drugs were obtained from Sigma-Aldrich except for minocycline- $\mathrm{HCl}$ and LY 354740, which were obtained from Tocris Bioscience. All drugs were bath-applied.

Computational modeling. A simplified computational model of the granule-Golgi system was constructed in Neuron (version 7.2; Carnevale and Hines, 2006). A single Golgi cell and 500 granule cells were simulated using published models of cerebellar granule cells and Golgi cells (Solinas et al., 2007; Simões de Souza and De Schutter, 2011). The spontaneous firing of the Golgi cell was silenced with a $-25 \mathrm{pA}$ current injection. All granule cells received input from four mossy fibers, which were modeled 
A

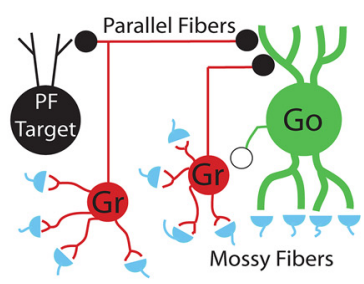

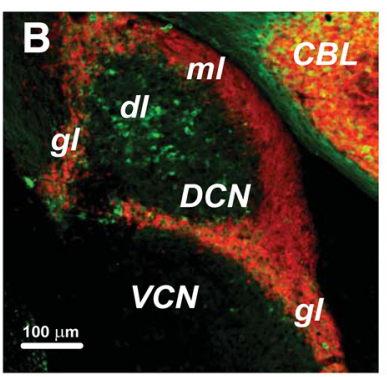

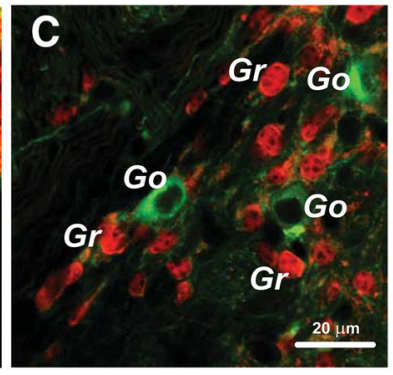

postsynaptic current (PSC) resulting from the $i^{\text {th }}$ presynaptic action potential is the product of the peak amplitude of the initial PSC $($ weight $)$, a depression variable $(D)$, and a facilitation variable $(F)$ as follows:

$$
\mathrm{PSC}_{i}=\text { weight } \times D_{i} \times F_{i}
$$

After each presynaptic action potential, $D$ is multiplied by a constant factor $d$, where $d<1$. $F$ is increased by a constant factor $f$, where $f>$ 1 . Both $D$ and $F$ decay back to 1 according to recovery time constants $\tau_{\mathrm{D}}$ and $\tau_{\mathrm{F}}$, respectively. For the Golgi-to-granule cell synapse, $d=0.81$, $\tau_{\mathrm{D}}=132 \mathrm{~ms}$. For the granule-to-Golgi cell synapse, $d=0.73, \tau_{\mathrm{D}}=60.9 \mathrm{~ms}, f=1.99$, and $\tau_{\mathrm{F}}=$ $38 \mathrm{~ms}$.

Simulations were run 20-100 times and the spike times of the nonbursting granule cells were binned into 1 or $2 \mathrm{~ms}$ bins for each run. The bin counts were averaged for the $50 \mathrm{~ms}$ preceding the first Golgi cell spike and a $t$ test was used to compare the bin counts after the Golgi spike with the bin counts during the preas synaptic conductances on the granule cell membrane. The mossy fiber-to-granule cell synapse was modeled using EPSC waveforms, NMDA receptor $\mathrm{Mg}^{2+}$ block, and short-term synaptic plasticity parameters from Schwartz et al. (2012). One to 10 granule cells received a burst of mossy fiber input that caused the cells to fire $10.2 \pm 0.1$ spikes at $109.1 \pm 0.7 \mathrm{~Hz}$. All nonbursting granule cells received an inhibitory input from the Golgi cell. A random number was selected from a uniform distribution to specify the number of bursting granule cells receiving feedback inhibition from the Golgi cell in a simulation run such that, on average, half of the bursting granule cells received feedback inhibition.

Only the bursting granule cells synapsed onto the Golgi cell and the synapse was placed onto the soma of the multicompartmental Golgi cell model (Solinas et al., 2007) in accordance with the fast rise times of EPSPs in paired granule-to-Golgi cell recordings $(20-80 \%$ rise time: $0.67 \pm$ $0.08 \mathrm{~ms}, n=10$ ). Experimental data from paired recordings was used to fit synaptic conductance waveforms and short-term synaptic plasticity. Synaptic conductance waveforms were modeled as being of the form:

$$
G(t)=\text { weight } \times \frac{1}{a_{\text {norm }}} \times\left(1-e^{\frac{-T}{\tau_{\text {rise }}}}\right)^{n} \times\left(d_{1} e^{\frac{-T}{\tau_{d_{1}}}}+d_{2} e^{\frac{-T}{\tau_{d_{2}}}}\right)
$$

where weight is the synaptic strength, $T=t-t_{\text {event }}, T \geq 0 ; a_{\text {norm }}$ is the peak amplitude of the waveform; $\tau_{\text {rise }}$ is the time constant of the rising phase; $d_{1-2}$ are the weighted percentages that each of the slow decay time constants contribute to the decay; and $\tau_{\mathrm{d} 1-2}$ are decay time constants (Rothman and Silver, 2014). Granule-to-Golgi cell EPSCs and Golgi-togranule cell IPSCs from paired recordings were fit to Equation 2. For the Golgi-to-granule cell inhibitory synapse, weight $=1.14 \mathrm{nS}, n=3, \tau_{\text {rise }}=$ $0.27 \mathrm{~ms}, d_{1}=60.99 \%, \tau_{\mathrm{d} 1}=2.66 \mathrm{~ms}, d_{2}=39.01 \%$, and $\tau_{\mathrm{d} 2}=13.56 \mathrm{~ms}$. For the granule-to-Golgi cell excitatory synapse, weight $=1.1 \mathrm{nS}, n=2$, $\tau_{\text {rise }}=0.17 \mathrm{~ms}, d_{1}=100 \%$, and $\tau_{\mathrm{d} 1}=0.66 \mathrm{~ms}$.

Weight for the granule-to-Golgi cell synapse was set so that the average latency to the first spike for the model Golgi cell when stimulated with a single granule cell input at $100 \mathrm{~Hz}$ was $57.9 \mathrm{~ms}$ after the start of the granule cell spike train, similar to the mean latency to the first IPSC observed in dual and single granule cell recordings (58.7 ms; see Fig. $5 C, E)$. Inhibitory synaptic weight was set to the corresponding conductance of the average IPSC in paired Golgi-to-granule cell recordings. In Figure $6 D$, the synaptic latency and weight of the Golgi-to-granule cell synapses were randomized by fitting experimentally observed distributions of synaptic weight and latency to probability density functions and assigning values probabilistically in simulations. Synaptic latencies were well fit by a normal distribution with a mean of $0.92 \mathrm{~ms}$ and an SD of 0.23 $\mathrm{ms}$. Synaptic weights were fit with a log-normal distribution with a mean of $1.14 \mathrm{nS}$ and an SD of $1.1 \mathrm{nS}$. The Varela et al. (1997) model of shortterm synaptic plasticity was used to model Golgi-to-granule and granuleto-Golgi cell synapses. In this model, the peak amplitude of the $i^{\text {th }}$

Golgi spike control period (Roberts and Trussell, 2010). The duration of inhibition was considered as the length of time after the onset of the IPSP for which the counts in contiguous bins were significantly different from the control period. For simulations in which 3-4 granule cells were bursting, there were 2 periods of inhibition separated by periods of $10 \mathrm{~ms}$ or more during which the bin count was not significantly different than the control period; in these cases, only the first period of inhibition was plotted in Figure 6D.

Statistics. All averages are reported as mean \pm SEM.

\section{Results}

\section{Golgi cells in the cochlear nucleus}

To determine whether single granule cells can provide suprathreshold excitation to Golgi cells, it was necessary to perform paired recordings between granule and Golgi cells. Although such recordings have been made in the cerebellar cortex (Vervaeke et al., 2012; Cesana et al., 2013), they have never been reported in the cochlear nucleus. Golgi cells were identified for whole-cell recording based upon their expression of GFP in the IG17 mouse line (Watanabe et al., 1998; Watanabe and Nakanishi, 2003; Irie et al., 2006), in which GFP-tagged human interleukin-2 receptor $\alpha$ subunit is expressed under the control of the mGluR2 promoter.

The spatial relationship between Golgi and granule cells was examined using triply transgenic mice in which granule cells express tdTomato and Golgi cells express GFP (Fig. $1 B, C$; see Materials and Methods). In fixed thin slices from this mouse, granule cells appeared to cluster around Golgi cells with their somas within $10-40 \mu \mathrm{m}$ of the Golgi cell soma. Because connection probability typically decreases with distance (Levy and Reyes, 2012), we targeted these granule cells located near the Golgi cell soma for paired recordings between granule and Golgi cells.

\section{Synaptic properties of unitary granule-to-Golgi cell inputs}

Action potentials (APs) in granule cells triggered EPSCs in Golgi cells in 75 of 227 dual recordings, corresponding to a connection probability of $33 \%$. Under voltage clamp at $-60 \mathrm{mV}$, these EPSCs were fully blocked by the $\alpha$-amino-3-hydroxy-5-methyl4-isoxazolepropionic acid receptor (AMPAR) antagonist GYKI 53665 (20 $\mu$ m; Paternain et al., 1995; Fig. 2A; $98 \pm 1 \%$ block, $n=3$ pairs), indicating that EPSCs recorded near resting potentials were mediated exclusively by AMPARs. $N$-methyl-D-aspartic acid 
receptor (NMDAR)-mediated EPSCs could be evoked by single granule cell APs at positive holding potentials, but the ratio of the NMDAR to the AMPAR EPSCs was low even at a holding potential of $+60 \mathrm{mV}$ (0.12 $\pm 0.03 ; n=9$ pairs).

AMPAR-mediated EPSCs had rapid monoexponential or biexponential decay kinetics (Table 1). The current-voltage relationship of AMPAR-mediated EPSCs showed rectification when $100 \mu \mathrm{M}$ spermine was included in the Golgi cell intracellular solution (Fig. $2 B, C$ ), but not when it was omitted from the intracellular solution (Fig. 2C). The difference in the IV relations between the spermine-containing and spermine-free recording conditions was significant at a holding potential of $+60 \mathrm{mV}(p<$ 0.05 , unpaired $t$ test). These results indicate that EPSCs are mediated, at least partly, by $\mathrm{Ca}^{+2}$-permeable AMPARs (Gardner et al., 2001; Liu and Cull-Candy, 2002), as in the cerebellum (but see Menuz et al., 2008; Cesana et al., 2013). The results also support the hypothesis that $\mathrm{Ca}^{2+}$ permeability of AMPARs is target dependent in cochlear nucleus because stellate cell target AMPARs are also $\mathrm{Ca}^{2+}$ permeable (Apostolides and Trussell, 2014) whereas cartwheel and fusiform cell target AMPARs are not (Gardner et al., 1999, 2001).

The granule-to-Golgi cell synapse showed prominent short-term facilitation in response to high-frequency trains of granule cell APs (5 APs, 90-100 Hz: EPSC5/EPSC1 ratio = $2.56 \pm 0.27, n=16$; Fig. $2 D, F)$. Trains of granule cell APs at 10 $\mathrm{Hz}$ did not produce short-term facilitation of EPSCs (EPSC5/ EPSC1 ratio $=1.10 \pm 0.10, n=6$ ). During the high-frequency train, failures to release were readily apparent and appeared to become less frequent for later stimuli in the train (Fig. 2E). To examine the change in release probability during facilitation, the probability of synaptic failures $F$ was measured during the train and plotted as $1-F$ (Fig. $2 F$ ). These data show that facilitation increased in exact proportion to the decline in synaptic failures when stimulating at high frequency, indicating that facilitation may be accounted for solely by an increase in release probability, as opposed to a postsynaptic effect.

\section{Synaptic properties of unitary Golgi-to-granule cell inputs}

We next examined the synaptic properties of unitary Golgi-togranule cell inputs. Golgi cell spikes evoked postsynaptic responses in granule cells in 43 of 110 dual recordings, yielding a connection probability of $38 \%$. Golgi cell spikes evoked IPSCs in granule cells that showed a variable degree of block by $5 \mu \mathrm{M}$ the $\mathrm{GABA}_{\mathrm{A}}$ receptor antagonist SR 95531 (range $94 \%$ to $-3 \%$ block; average of $50 \pm 18 \%$ block, $n=6$ ), indicating a variable contribution of GABA to synaptic transmission in these cell pairs. Figure $3 A$ shows an example pair in which most of the IPSC was blocked by SR 95531. Figure 3B shows a different pair in which the IPSC was insensitive to SR 95531 but was abolished by $1 \mu \mathrm{M}$ of the glycine receptor antagonist strychnine. Therefore, our results indicate that Golgi cells inhibit granule cells by releasing GABA and/or glycine. Evoked IPSCs showed failure rates of 15\% (Table
B
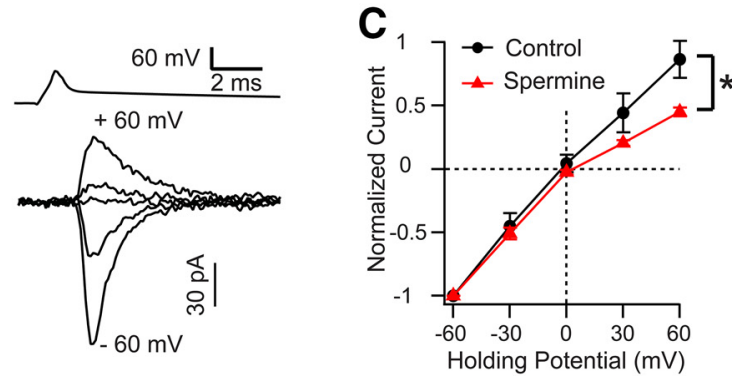

E

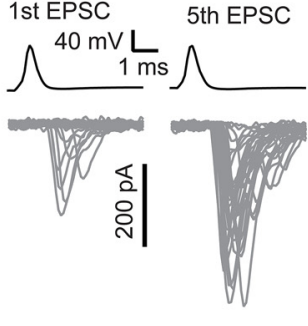

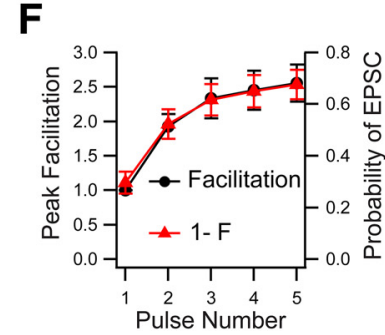

Figure 2. Properties of AMPAR-mediated EPSCs at the granule-to-Golgi cell synapse. A, EPSC evoked in Golgi cell (bottom) by AP in presynaptic granule cell (top) was blocked by $20 \mu \mathrm{m}$ GYKI 53665 (red trace). B. AMPAR-mediated EPSC isolated by bath in of R-CPP, SR 95531, and strychnine obtained with $100 \mu \mathrm{m}$ spermine included in the recording pipette. Golgi cell was cell AP trains at $90-100 \mathrm{~Hz}(n=16)$. Circles show normalized peak current of the EPSC. On the same plot is EPSC probability (triangles, 1 - synaptic failure frequency), which matches exactly the average increase in EPSC amplitude $(n=16)$.

1), suggesting that Golgi cells mediate reliable inhibition of granule cells.

Indeed, when postsynaptic granule cells were made to fire through depolarizing current injection, a single AP in the presynaptic Golgi cell led to an IPSP and a cessation in granule cell firing (Fig. 3C). The granule cell interspike interval increased significantly from $17.0 \pm 3.7 \mathrm{~ms}$ to $37.5 \pm 7.8 \mathrm{~ms}$ after the Golgi cell AP ( $n=8$; paired $t$ test, $p=0.01)$. Granule cell spikes from 8 pairs were sorted into $1 \mathrm{~ms}$ bins and summed together and are shown in Figure 3D, revealing that single Golgi cell APs reduced granule cell firing for $\sim 25 \mathrm{~ms}$. As expected for a reliable synapse with a low rate of synaptic failure, IPSCs evoked by trains of Golgi cell APs depressed (10 APs, $100 \mathrm{~Hz}$ : IPSC10/IPSC1 ratio $=0.33 \pm$ $0.04, n=10$; Fig. $3 E$ ), consistent with a high release probability at this synapse (Zucker and Regehr, 2002).

Golgi cells are the only source of inhibition onto granule cells Inhibition of cochlear nucleus granule cells has not been extensively studied and it is not clear whether Golgi cells are the only source of inhibition onto granule cells (Alibardi, 2002; Alibardi, 2003). To determine whether Golgi cells are the sole source of inhibition to granule cells, as in the cerebellum (Eccles et al., 1967; Hamann et al., 2002), inhibitory inputs to granule cells were stimulated extracellularly in the presence of glutamate receptor antagonists. Because Golgi cells are the only inhibitory cells in the cochlear nucleus that express the mGluR2 or mGluR3 receptor (Jaarsma et al., 1998; Irie et al., 2006) and activation of mGluR2 receptors on Golgi cell axon terminals results in a reduction of release probability (Mitchell and Silver, 2000), it was rea- 
Table 1. Synaptic properties of unitary Golgi-to-granule and granule-to-Golgi synapses

\begin{tabular}{|c|c|c|c|c|c|c|c|c|c|}
\hline Connection (no. of pairs) & Synaptic strength (nS) & Success amplitude (nS) & Failure rate & $\begin{array}{l}\text { Synaptic } \\
\text { delay (ms) }\end{array}$ & Rise time (10-90\%; ms) & $\tau_{\text {fast }}$ (ms) & $\tau_{\text {slow }}(\mathrm{ms})$ & $\%$ fast & Weighted $\tau$ (ms) \\
\hline Granule-to-Golgi (21) & $0.24 \pm 0.04$ & $0.77 \pm 0.07$ & $0.71 \pm 0.03$ & $0.89 \pm 0.04$ & $0.33 \pm 0.02$ & $0.39 \pm 0.05$ & $1.73 \pm 0.33$ & $71.55 \pm 5.95$ & $0.85 \pm 0.045$ \\
\hline Golgi-to-granule (29) & $1.32 \pm 0.21$ & $1.44 \pm 0.20$ & $0.15 \pm 0.03$ & $0.98 \pm 0.04$ & $0.68 \pm 0.05$ & $6.03 \pm 0.69$ & $31.69 \pm 3.46$ & $65.61 \pm 3.13$ & $14.90 \pm 1.38$ \\
\hline
\end{tabular}

For granule-to-Golgi synaptic parameters, there were 15 pairs in which EPSCs were best fit by a single exponential and 6 pairs in which EPSCs were best fit by a double exponential. $\tau_{\text {fast }}$ and $\tau_{\text {slow }}$ refer to fits for the pairs with bi-exponential decay, whereas Weighted $\tau$ includes mono-exponential fits and weighted bi-exponential fits.

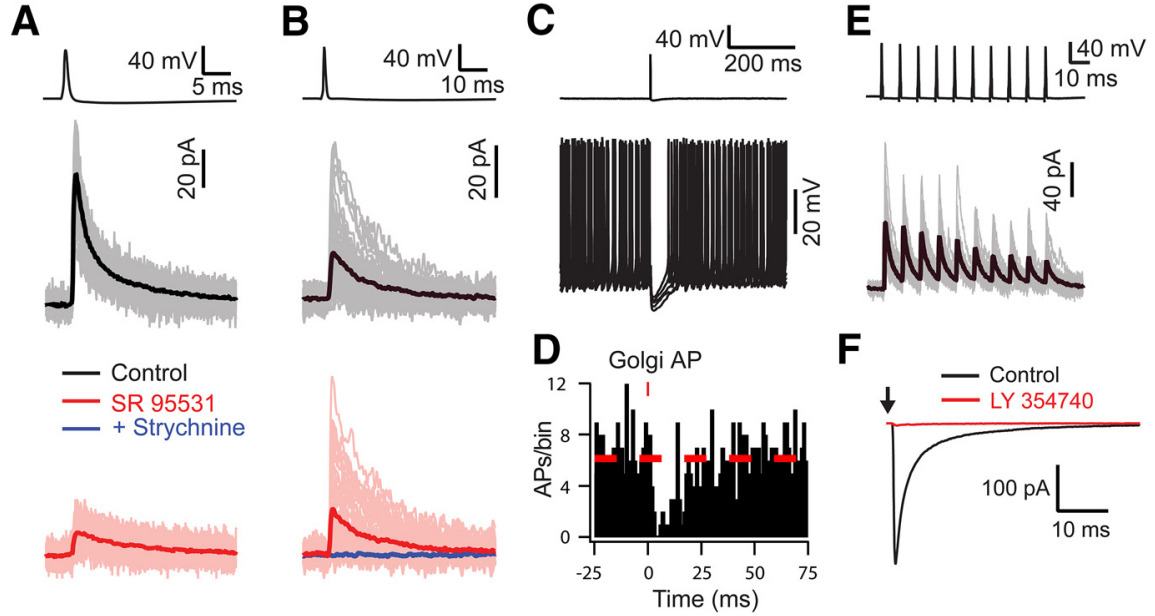

Figure 3. Properties of Golgi-to-granule cell inhibitory synapses. $A$, IPSC evoked in the postsynaptic granule cell by presynaptic Golgi cell AP. Top, Individual traces (gray) are shown along with the average (black). Bottom, IPSCs were reduced in amplitude by bath application of $5 \mu \mathrm{m}$ SR 95531 (individual traces in light red and average in darker red). $\boldsymbol{B}$, IPSC evoked in a different paired recording between a presynaptic Golgi cell and granule cell. Top, Individual traces (gray) are shown along with the average (black). Bottom, SR $95531(5 \mu \mathrm{M}$ ) failed to block the IPSC (individual traces in red and average in darker red), but subsequent addition of 1 $\mu \mathrm{m}$ strychnine fully blocked the IPSC (average in blue). C, Granule cell (bottom) was depolarized with current injection to evoke spiking, and a single AP was evoked in a presynaptic Golgi cell (top). Golgi cell AP evoked an IPSP in the granule cell that caused a pause in spiking. $\boldsymbol{D}$, Histogram showing binned and summed granule cell spikes for 10 trials each in 8 pairs. Red vertical bar indicates the time of the peak of the Golgi cell AP (at $0 \mathrm{~ms}$ ). $\boldsymbol{E}, \mathrm{A} 100 \mathrm{~Hz}$ train of APs in a presynaptic Golgi cell (top) evoked depressing IPSCs in the postsynaptic granule cell (bottom; individual traces in gray and average in black). $\boldsymbol{F}$, Extracellular stimulation of inhibitory inputs to granule cell isolated in the presence of NBQX and R-CPP evoked an IPSC that was almost completely blocked by a $300 \mathrm{~nm}$ concentration of the mGluR2/3 agonist LY 354740 , suggesting that all inhibitory inputs to granule cells express mGluR2/3 receptors. Arrow indicates the timing of stimulation. Stimulus artifact has been removed for clarity. Note that IPSC is inward due to the use of a high- $\mathrm{Cl}^{-}$intracellular solution (see Materials and Methods).

soned that if an mGluR2/3 receptor agonist reduced the evoked IPSC amplitude, this would strongly suggest that Golgi cells are the primary source of inhibition to cochlear nucleus granule cells. Bath application of $300 \mathrm{nM}$ to $1 \mu \mathrm{M}$ concentrations of the mGluR2/3 agonist LY354740 blocked $92 \pm 4 \%$ of the IPSC $(n=$ 5; Fig. $3 F$ ). These results suggest that all inhibitory inputs to granule cells are mGluR2-expressing Golgi cells. This conclusion allowed for estimation of the average number of Golgi cells synapsing onto a granule cell by dividing the inhibitory synaptic conductance using strong extracellular fiber stimulation (5.04 \pm $2.37 \mathrm{nS}, n=13$ ) by the unitary inhibitory synaptic conductance obtained in paired recordings ( $1.14 \pm 0.18 \mathrm{nS}, n=35)$, which indicates that at least 5 Golgi cells contact each granule cell.

\section{Reciprocally connected granule-Golgi cell pairs}

Of 98 dual recordings between granule and Golgi cells in which we were able to test for both inhibitory and excitatory connections, 13 pairs were connected reciprocally (13\% of dual recordings). The percentage of reciprocally connected granule-Golgi cell pairs we observed is equal to the product of the excitatory and inhibitory connection probabilities $(0.33 \times 0.38=0.13)$, suggesting that the reciprocal connections occurred at the frequency expected given the excitatory and inhibitory connection proba- bilities. An example reciprocal pair is shown in Figure 4. Spiking in the granule cell evoked EPSPs in the Golgi cell (onset of EPSPs denoted by asterisk in Fig. 4A) and a train of Golgi cell APs triggered by current injection inhibited firing of the granule cell (duration of Golgi cell spiking shown by gray bar in Fig. $4 A$ ). The granule cell spike-triggered average of Golgi cell membrane voltage for the same pair as in Figure $4 A$ is shown in Figure $4 B$, confirming that granule cell spikes evoked shortlatency EPSPs in the Golgi cell.

\section{Single granule cells trigger Golgi cell spiking and IPSCs in granule cells} Can single granule cells provide suprathreshold excitation to Golgi cells? To answer this question, a $100 \mathrm{~Hz}$ train of 10 APs was evoked in granule cells in connected granule-to-Golgi cell pairs (Fig. $5 A)$. The AP train evoked Golgi cell spikes in 7 of 17 pairs ( $41 \%$ of pairs), with Golgi cells firing an average of $0.8 \pm 0.2$ spikes per granule cell train (range, $0.1-2.0$ postsynaptic APs per presynaptic train). Golgi cell spikes typically occurred after the granule cell had fired several times (average latency from first granule cell spike to first Golgi cell spike: $73.6 \pm 1.9 \mathrm{~ms}$; Fig. $5 B)$. Although we cannot rule out the contribution of temporal summation in bringing the Golgi cell to threshold, the relatively low initial efficacy and the pronounced synaptic facilitation of the granule-toGolgi cell synapse may explain the relatively long latency between the start of the granule cell AP train and the first spike in the Golgi cell.

The results shown in Figure 5, $A$ and $B$, led to the prediction that a burst of APs in a single granule cell will after some delay evoke IPSCs onto the various granule cells innervated by that Golgi cell. We first tested this prediction by evoking spiking in one granule cell in current clamp while simultaneously recording from another granule cell in voltage clamp (Fig. $5 C$ ). In 6 of 69 dual recordings, a 100 or $200 \mathrm{~Hz}$ train of 10 APs in one granule cell resulted in IPSCs in the simultaneously recorded granule cell ( 6 of 132 directions tested for probability of 5\%). Each granule cell train evoked $0.9 \pm 0.1$ IPSCs in the simultaneously recorded granule cell (range, 1.4-0.5 IPSCs per granule cell train). The IPSCs were blocked by NBQX (Fig. $5 C$, red line; $n=2$ ) and by SR 95531 and strychnine $(n=1)$, as expected for disynaptic IPSCs evoked by glutamate release from granule cells onto Golgi cells and subsequent release of GABA and/or glycine. The IPSC occurred $54.2 \pm 3.1 \mathrm{~ms}$ after the peak of the first granule cell spike for the $100 \mathrm{~Hz}$ train $(n=4)$ and $32.6 \pm 2.1 \mathrm{~ms}$ for the $200 \mathrm{~Hz}$ train 
$(n=2$; Fig. $5 D)$. The apparently earlier onset of Golgi cell spiking in the experiments shown in Fig. 5, $C$ and $D$, compared with those in Fig. 5, $A$ and $B$, as inferred from the timing of the IPSC onto the granule cell, may have resulted from the hyperpolarizing current that was typically injected into Golgi cells to prevent spontaneous spiking in the paired granule-to-Golgi cell recordings (see Materials and Methods).

It was difficult to determine whether the spiking granule cell also evoked inhibition onto itself (i.e., feedback inhibition) in the experiments in Figure 5, C and $D$, possibly because the large spikemediated conductances obscured IPSPs. However, because some granule cells are reciprocally connected to Golgi cells (Fig. 4), we reasoned that evoking escaping spikes in voltage-clamped granule cells (Barbour, 1993) might evoke IPSCs that could easily be distinguished from action currents by their relatively slow decay (Table 1). Escaping spikes were evoked in granule cells patched with a KCl-based intracellular solution by $1 \mathrm{~ms}$ depolarization to $0 \mathrm{mV}$ from a holding potential of $-60 \mathrm{mV}$. A $10 \mathrm{AP}, 100 \mathrm{~Hz}$ train of escaping spikes evoked IPSCs in 5 of 85 recordings from single granule cells ( $6 \%$ of cells). The IPSC was blocked by NBQX (Fig. $5 E ; n=2)$ and by SR 95531 and strychnine $(n=2)$, confirming the disynaptic nature of the IPSC. Each granule cell train evoked $1.2 \pm 0.3$ IPSCs (range, 0.7-2.0), and occurred 64.1 $\pm 3.6 \mathrm{~ms}$ after the peak of the first granule cell action current (Fig. $5 F$ ). Together, these results indicate that single granule cells can excite Golgi cells and thereby evoke IPSCs onto themselves and other granule cells. Because single Golgi cell spikes can inhibit granule cell firing (Fig. $3 C, D$ ), our results show that activity in a single granule cell can lead to inhibition in other granule cells.

\section{Computational modeling of granule-cell-evoked inhibition}

What effect does a high-frequency burst of spikes in a small number of granule cells have on the activity of a larger population of granule cells? A single Golgi cell projects to a large number of granule cells (Eccles et al., 1967), so even a single Golgi cell spike evoked by a single bursting granule cell could affect the activity of many granule cells. We turned to a simplified computational model of the cerebellar granular layer to answer this question (Fig. 6A; see Material and Methods). We hypothesized that a burst of spikes in one granule cell synapsing onto a Golgi cell will temporarily silence the spontaneous firing of the larger population of granule cells receiving an inhibitory input from the Golgi cell. The nonbursting granule cells will be referred to as "background" granule cells.

In the model, 490 background granule cells received input from 4 mossy fibers firing at an average rate of $5 \mathrm{~Hz}$ each, similar to the observed spontaneous firing rates from in vivo whole-cell recordings of mossy fibers (Rancz et al., 2007). The lowfrequency mossy fiber input evoked low-frequency background granule cell spiking $(1.0 \pm 0.1 \mathrm{~Hz})$ caused mainly by coincidence of two or more EPSPs, similar to rates observed in vivo (Chadderton et al., 2004; Loewenstein et al., 2005; Ruigrok et al., 2011; Duguid et al., 2012). One granule cell received a burst of mossy fiber input that evoked a train of $10.2 \pm 0.1$ spikes at $109.1 \pm 0.7$ $\mathrm{Hz}$, similar to bursts evoked in granule cells by sensory stimula- tion in vivo (Chadderton et al., 2004; Jörntell and Ekerot, 2006; Bengtsson and Jörntell, 2009) and to our paired recordings in Figure 5 . The burst of spikes in the single granule cell evoked a single Golgi cell spike, as in our experimental data. The IPSP evoked by the Golgi cell spike led to an inhibition in the firing rate of the background granule cells that was statistically significant for $30 \mathrm{~ms}$ (Fig. 6B, C).

Because granule cells may be either reciprocally or nonreciprocally connected to the Golgi cell (Fig. 4), the firing rates of bursting granule cells with and without reciprocal inhibition were compared. The impact of the IPSP on bursting granule cells was relatively weak, reducing the average number of APs fired by bursting granule cells by $0.6 \pm 0.1$ spikes and the average frequency of spiking by only $6.6 \pm 0.7 \mathrm{~Hz}$. Therefore, the main effect of the IPSP was to inhibit the firing of the background granule cells. Because a single granule cell will not synapse onto all of the parallel fiber target cells (Barbour, 1993; Roberts and Trussell, 2010), the Golgi cell may act to "inform" several target cells that a single granule cell has fired a burst by inhibiting the activity of the background granule cells (see Discussion).

In the cerebellum, a single mossy fiber terminal synapses onto 10-100 granule cells (Jakab and Hámori, 1988; Billings et al., 2014; Ritzau-Jost et al., 2014). Assuming that one-third of the granule cells receiving input from a particular mossy terminal synapse onto a given Golgi cell, this suggests that bursts of activity at a single terminal may result in an increase in the activity of several granule cells. Therefore, the number of bursting granule cells was progressively increased from 1 to 10 granule cells, which resulted in an increasingly prolonged duration of inhibition of the background population of granule cells (Fig. 6D, black line). However, the effect of changing the number of bursting granule cells on the duration of inhibition appeared to saturate with four or more bursting granule cells.

For the simulations described so far, the Golgi-to-granule cell synaptic latency and synaptic strength was the same for all of the granule cells in the simulation. To determine how the duration of inhibition is affected by changing the number of bursting granule cells under more realistic conditions, simulations were repeated with randomized synaptic latencies and strengths drawn from distributions based upon the experimental data from Golgi-to- 
A
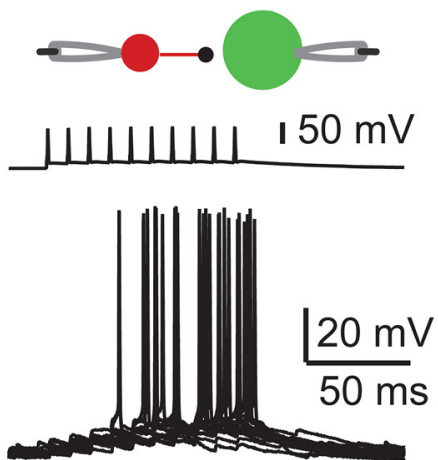

C
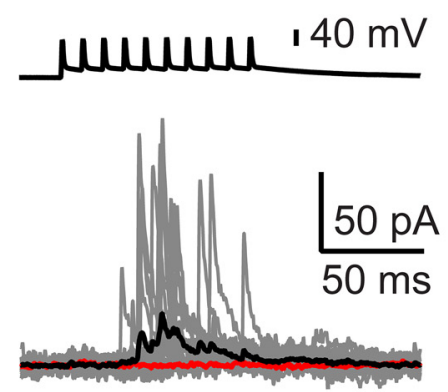

E

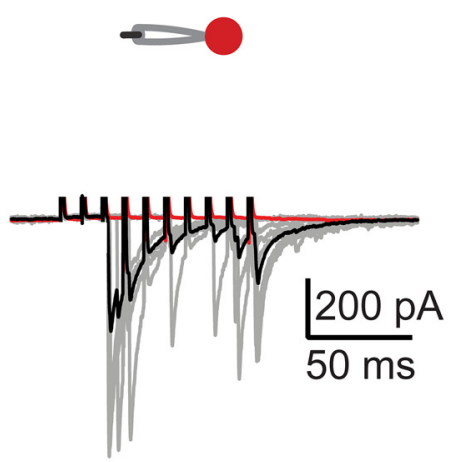

B

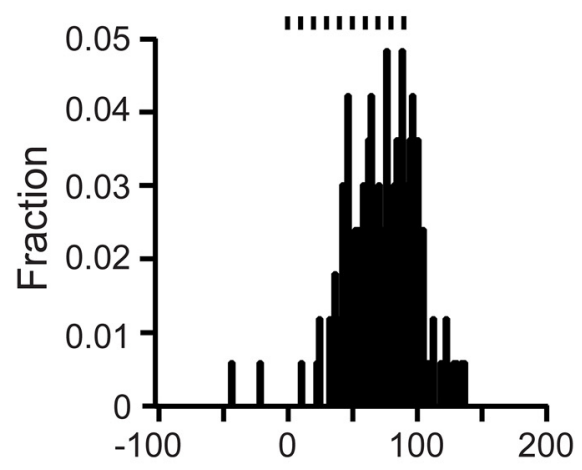

D

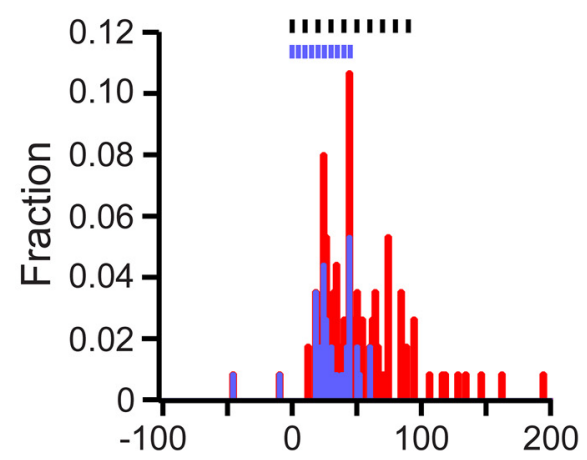

$\mathbf{F}$

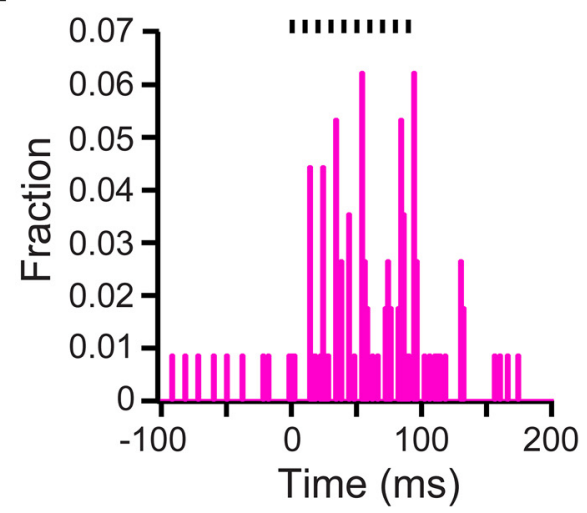

Figure 5. Single granule cells can evoke spiking in Golgi cells and IPSCs onto granule cells. $A, A 100 \mathrm{~Hz}, 10 \mathrm{AP}$ train of granule cell spikes (top) evoked spikes in the Golgi cell with variable latency and that typically occurred only after multiple granule cell APs. $\boldsymbol{B}$, Summary graph of distribution of timing of Golgi cell APs for all pairs in which granule cell firing evoked Golgi spiking $(n=7)$. The timing of Golgi cell spikes was binned into $2 \mathrm{~ms}$ bins and 0 ms was set as the peak of the first granule cell AP in the train. Vertical black marks indicate the timing of granule cell APs. C, A $100 \mathrm{~Hz}, 10$ AP train of APs in one granule cell (top) evoked IPSC in a second granule cell (bottom). Gray traces show overlaid single trials and the thick black line is the average of the trials. NBQX blocked the IPSCs (as shown by thick red line, which is the average of several trials in the presence of NBQX), confirming that the IPSCS were evoked by glutamate release from the granule cell train. $\boldsymbol{D}$, Summary graph as in $\boldsymbol{B}$ for distribution of timing of IPSCs for 2 pairs in which granule cell fired at $200 \mathrm{~Hz}$ (blue bars) and 4 pairs in which granule cell fired at $100 \mathrm{~Hz}$ (red bars). Blue vertical bars indicate the timing of granule cell APs for the $200 \mathrm{~Hz}$ train and black bars indicate the timing for the $100 \mathrm{~Hz}$ train. $\boldsymbol{E}, \mathrm{A} 100 \mathrm{~Hz}, 10 \mathrm{action}$ current train evoked by $1 \mathrm{~ms}$ depolarization of granule cell from -60 to $0 \mathrm{mV}$ triggers IPSCs after the third or later action current in the train. Gray traces show overlaid trials and black line is the average of trials. NBQX blocked the IPSCs (red line). Granule cell was patched with a KCl-based intracellular solution, leading to inward-directed IPSCs (see Materials and Methods). Action currents have been partially deleted for clarity. F, Summary graph as in D for IPSCs evoked in single granule cells by escaping spikes $(n=5)$.

granule cell paired recordings (see Materials and Methods). Even under randomized conditions, bursting in granule cells was still able to significantly inhibit background granule cell firing, with the duration of inhibition increasing with the number of bursting granule cells (Fig. 6D, red line). Interestingly, under these more realistic conditions, there was a greater range over which the duration of inhibition increased with the number of bursting granule cells. Therefore, bursts of spikes in a small number of granule cells can inhibit other granule cells firing at low rates in response to mossy fiber input and the time during which the nonbursting granule cells are inhibited increases with the number of bursting granule cells.

\section{Discussion}

We have shown that a burst of spikes in single granule cells can evoke Golgi cell spiking and recruit inhibition onto granule cells of the cochlear nucleus. Using paired patch-clamp recordings, we first characterized the granule-Golgi cell network, which has been extensively studied in cerebellum but has received little attention in the cerebellum-like cochlear nucleus and electrosensory lobe of weakly electric mormyrid fish. Single Golgi cells released GABA and/or glycine onto granule cells and mediated potent inhibition of granule cell firing. Granule cells made excitatory synapses onto Golgi cells that released glutamate onto postsynaptic $\mathrm{Ca}^{2+}$-permeable AMPARs and underwent short-term synaptic facilitation.

Trains of APs at $100 \mathrm{~Hz}$ in a single granule cell were sufficient to evoke spiking in $\sim 40 \%$ of connected granule-toGolgi cell pairs. Firing of one granule cell evoked IPSCs in another granule cell in $5 \%$ of granule-granule cell dual recordings and in the same granule cell in $6 \%$ of single granule cell recordings. Last, simulations using experimentally constrained parameters confirmed that a train of APs in a single granule cell could inhibit the firing of other granule cells for tens of milliseconds. Furthermore, as the number of bursting granule cells was increased, the duration of inhibition of the nonbursting granule cells lengthened. Therefore, bursting in a small number of granule cells may inhibit activity in the larger population of granule cells innervated by a Golgi cell. Our results challenge the view that granule cell synapses onto Golgi cells are too weak to excite Golgi cells (Dieudonné, 1998; Xu and Edgley, 2008; Prsa et al., 2009), at least in cochlear nucleus.

A single granule cell would be expected to influence the firing of a limited subset of all other granule cells; in this way, feedback inhibition can control transmission of signals from mossy fibers but still maintain independence among different groupings of cells. Although it is difficult to extrapolate findings from dual recordings to the circuit level (Rieubland et al., 2014), our esti- 
mate of 5-6\% granule cells sensing feedback from one granule cell is what would be expected based on connection probabilities and synaptic strengths in the circuit. If it is assumed that each granule cell only provides excitatory input to one Golgi cell (as might be expected from the low degree of shared parallel fiber input in cochlear nucleus; Roberts and Trussell, 2010), then the probability that a granule cell synapses onto a particular Golgi cell that then synapses onto the other granule cell is $13 \%$ (product of granule-to-Golgi cell and Golgi-to-granule cell connection probabilities: $0.33 \times 0.38=0.13)$. Moreover, if $41 \%$ of these granule-to-Golgi synapses are strong enough to evoke Golgi cell spiking (as observed in paired granule-toGolgi cell recordings), then the probability that spiking in one granule cell evokes IPSCs in another is only $5 \%(0.13 \times 0.41=0.05)$, as was observed. However the effects of tissue slicing may reduce the magnitude of Golgi cell projections so this value must be a lower estimate. Another contributing factor is that, with the convergence of even two granule cells onto a Golgi cell, the spike threshold will be more reliably reached and inhibition more pronounced. Optical methods for circuit analysis applied to thicker tissue sections may provide more accurate evaluation of the impact of single or multiple granule cells.

\section{Inhibition of granule cells in the cerebellum and cerebellum-like systems}

Classically, Golgi cells have been thought

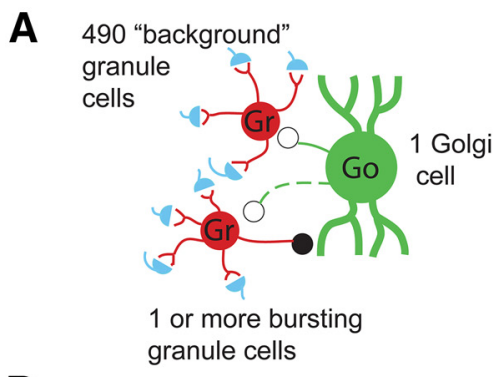

B

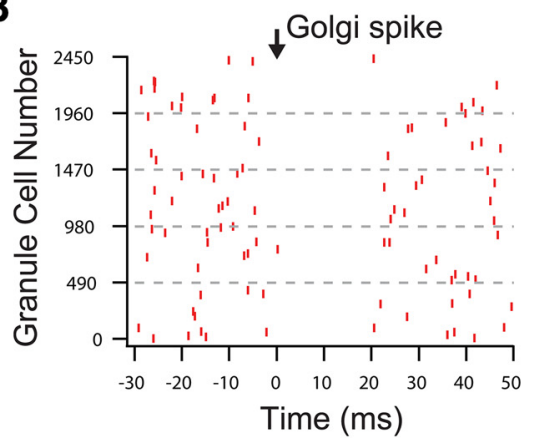

C

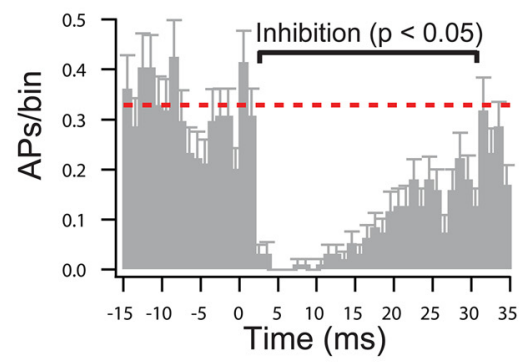

D

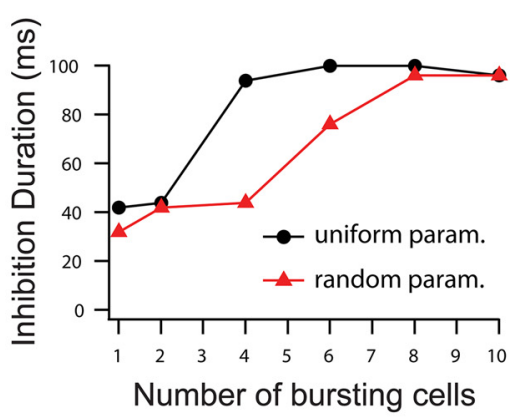

Figure 6. Computational modeling predicts that bursts of spiking in a small number of granule cells can evoke inhibition of granule cells firing in response to spontaneous mossy fiber EPSPs. A, Schematic of the model. A total of 490 granule cells (Gr, red), called "background" granule cells, received excitatory input from 4 mossy fibers (blue) firing at $5 \mathrm{~Hz}$, generating low-frequency granule cell firing (see text). The background granule cells all received inhibitory input from a single Golgi cell (Go, green), but for simplicity, the background cells did not synapse onto the Golgi cell. One to 10 granule cells received a burst of mossy fiber input that evoked a burst of APs. The bursting granule cells provided excitatory input to the Golgi cell and approximately half of the bursting granule cells also received feedback inhibition from the Golgi cell (see Materials and Methods). $\boldsymbol{B}$, Raster plot from 5 runs of the simulation in which the Golgi cell fired an AP at a time of $0 \mathrm{~ms}$ (as indicated by arrow) in response to a burst of $10 \mathrm{APs}$ at $\sim 100 \mathrm{~Hz}$ in a single granule cell. Each red mark indicates the timing of an AP in a background granule cell. Bursting granule cell APs are not shown. C, APs in the background granule cells were binned into $1 \mathrm{~ms}$ bins for 100 runs of the simulation. The Golgi cell AP occurred at 0 ms. Red dotted line indicates the average number of APs per bin for the 50 ms period immediately preceding the Golgi cell spike. The black bar indicates the duration of inhibition, the time over which the number of APs per bin was significantly different from the bin count for the control period ( $t$ test, $p<0.05$ ). $D$, The number of bursting granule cells was varied from 1 to 10 under 2 different network conditions: in the first condition, the synaptic latency and synaptic strength of the inhibitory Golgi-to-granule cell synapse was uniform (black circles); in the second condition, the parameters were randomized among the different background granule cells (red triangles). The duration of inhibition was measured as in $\boldsymbol{C}$.

to have a gain control function in the cerebellum, whereby increased granule cell or mossy fiber activation excites Golgi cells and inhibits granule cell spiking (Marr, 1969; Albus, 1971; Billings et al., 2014). Similarly, cerebellar granule cells are subject to tonic inhibition through $\mathrm{GABA}_{\mathrm{A}}$ Rs containing both the $\alpha 6$ and the $\delta$ subunit (Brickley et al., 1996; Hamann et al., 2002; Rossi et al., 2003), which controls the gain of granule cell spiking in response to mossy input (Mitchell and Silver, 2003; Duguid et al., 2012). Despite the considerable developmental, genetic, morphological, and physiological similarity between granule cells in the cerebellum and in cerebellum-like systems (Funfschilling and Reichardt, 2002; Bell et al., 2008), granule cells in the cochlear nucleus and mormyrid electrosensory lobe appear to lack tonic inhibition (Zhang et al., 2007; Balakrishnan and Trussell, 2008). Therefore, although tonic inhibition seems to be important enough in the cerebellum that knock-out of the $\alpha 6$ and the $\delta$ subunit is compensated fully by upregulation of a $\mathrm{K}^{+}$leak conductance (Brickley et al., 2001), tonic inhibition onto granule cells is not a general operating principle of cerebellum-like systems. However, Golgi cell firing induces inhibitory postsynaptic events in granule cells in the cerebellum and in cerebellum-like systems (Rossi and Hamann, 1998; Zhang et al., 2007; Balakrishnan et al., 2009), suggesting that Golgi-cell-mediated fast synaptic inhibition is a conserved network motif in these systems. The sources of excitatory input driving Golgi cell spiking in vivo are unknown, but Golgi cells receive excitatory synaptic input from granule cells, mossy fibers, and possibly climbing fibers in the cerebellum (Eccles et al., 1967; but see Galliano et al., 2013a) and auditory nerve fibers in cochlear nucleus (Mugnaini et al., 1980; Ferragamo et al., 1998).

Possibly because granule cell synapses onto Golgi cells have previously been considered less important in exciting Golgi cells (Dieudonné, 1998; Xu and Edgley, 2008; Prsa et al., 2009; but see Cesana et al., 2013), most studies have focused on firing of Golgi cells evoked by mossy fiber stimulation, which leads to feedforward inhibition of granule cells (Mapelli and D'Angelo, 2007; Kanichay and Silver, 2008). Mossy fiber activation has been hypothesized to lead to a limited time window during which the granule cell can spike in response to mossy fiber EPSPs before it is inhibited by feed-forward inhibition (D'Angelo and De Zeeuw, 2009). However, because suprathreshold excitation of Golgi cells requires the activation of multiple mossy fibers (Kanichay and Silver, 2008; Vervaeke et al., 2012), whereas even a single mossy fiber can drive granule cell firing (Rancz et al., 2007; Arenz et al., 2009; Rothman et al., 2009), feed-forward inhibition is not likely to occur under conditions of sparse mossy fiber activation. In contrast, high-frequency firing in only a single mossy fiber could lead to a burst of spikes in its target granule cells, thereby generating feedback inhibition in other granule cells. Therefore, whereas feed-forward inhibition may occur under conditions of 
abundant mossy fiber activation, bursts in a small number of granule cells may evoke feedback inhibition under conditions of sparse mossy fiber activation. Although we have shown that a train of highfrequency spikes in a single granule cell evokes inhibition onto granule cells in cochlear nucleus, such an experiment has not been performed in the cerebellum, so whether this phenomenon occurs in the cerebellum awaits experimental verification.

\section{Possible circuit functions of bursts in single granule cells}

Cerebellar granule cells appear to encode sensory stimuli by a burst of spikes (Chadderton et al., 2004; Jörntel and Ekerot, 2006; Arenz et al., 2009). However, mossy fibers in the cerebellum and electrosensory lobe are also spontaneously active (van Kan et al., 1993; Sawtell, 2010; Kennedy et al., 2014), which leads to lowfrequency granule cell firing (Chadderton et al., 2004; Ruigrok et al., 2011; Duguid et al., 2012). Furthermore, cochlear nucleus, electrosensory lobe, and the vestibulocerebellum contain unipolar brush cells, local excitatory interneurons that provide input to granule cells and are spontaneously active (Russo et al., 2007; Ruigrok et al., 2011; Kennedy et al., 2014). The resulting lowfrequency firing of granule cells appears to be quite sensitive to inhibition from Golgi cells (Fig. 6). Therefore, parallel fiber target neurons that do not receive input from the bursting granule cell(s) may receive reduced excitation from their source granule cells due to the inhibition triggered by the bursting granule cell(s). Due to the high rate of divergence of Golgi cell axons onto granule cells, Golgi cells may act to inform parallel fiber target neurons of bursts in one or more granule cells by decreasing the activity of the "background" granule cells, thus broadcasting the activity of a small number of bursting granule cells to a large number of parallel fiber target neurons. This function of Golgi cells may be particularly relevant in the cochlear nucleus, where there is little shared parallel fiber input among target neurons (Roberts and Trussell, 2010), and in the cerebellum, where the majority of granule cell synapses onto Purkinje cells are silent (Isope and Barbour, 2002; Brunel et al., 2004). The major effect of the decrease in background parallel fiber input evoked by a burst in a small number of granule cells may be a decrease in the activity of molecular layer interneurons because parallel fibers are particularly effective at exciting these cells (Barbour, 1993; Carter and Regehr, 2002). Therefore, a burst of spikes in even a single granule cell may have a circuit-wide effect.

\section{References}

Albus JS (1971) A theory of cerebellar function. Math Biosci 10:25-61. CrossRef

Alibardi L (2002) Immunocytochemistry of glycine in small neurons of the granule cell areas of the guinea pig dorsal cochlear nucleus: a post-embedding ultrastructural study. Histochem J 34:423-434. CrossRef Medline

Alibardi L (2003) Ultrastructural distribution of glycinergic and GABAergic neurons and axon terminals in the rat dorsal cochlear nucleus, with emphasis on granule cell areas. J Anat 203:31-56. CrossRef Medline

Apostolides PF, Trussell LO (2014) Chemical synaptic transmission onto superficial stellate cells of the mouse dorsal cochlear nucleus. J Neurophysiol 111:1812-1822. CrossRef Medline

Arenz A, Bracey EF, Margrie TW (2009) Sensory representations in cerebellar granule cells. Curr Opin Neurobiol 19:445-451. CrossRef Medline

Balakrishnan V, Trussell LO (2008) Synaptic inputs to granule cells of the dorsal cochlear nucleus. J Neurophysiol 99:208-219. Medline

Balakrishnan V, Kuo SP, Roberts PD, Trussell LO (2009) Slow glycinergic transmission mediated by transmitter pooling. Nat Neurosci 12:286-294. CrossRef Medline

Barbour B (1993) Synaptic currents evoked in Purkinje cells by stimulating individual granule cells. Neuron 11:759-769. CrossRef Medline

Beierlein M, Fioravante D, Regehr WG (2007) Differential expression of posttetanic potentiation and retrograde signaling mediate target-dependent shortterm synaptic plasticity. Neuron 54:949-959. CrossRef Medline
Bell CC, Han V, Sawtell NB (2008) Cerebellum-like structures and their implications for cerebellar function. Annu Rev Neurosci 31:1-24. CrossRef Medline

Bengtsson F, Jörntell H (2009) Sensory transmission in cerebellar granule cells relies on similarly coded mossy fiber inputs. Proc Natl Acad Sci U S A 106:2389-2394. CrossRef Medline

Billings G, Piasini E, Loorincz A, Nusser Z, Silver RA (2014) Network structure within the cerebellar input layer enables lossless sparse encoding. Neuron 83:960-974. CrossRef Medline

Brickley SG, Cull-Candy SG, Farrant M (1996) Development of a tonic form of synaptic inhibition in rat cerebellar granule cells resulting from persistent activation of GABAA receptors. J Physiol 497:753-759. CrossRef Medline

Brickley SG, Revilla V, Cull-Candy SG, Wisden W, Farrant M (2001) Adaptive regulation of neuronal excitability by a voltage-independent potassium conductance. Nature 409:88-92. CrossRef Medline

Brunel N, Hakim V, Isope P, Nadal JP, Barbour B (2004) Optimal information storage and the distribution of synaptic weights: perceptron versus Purkinje cell. Neuron 43:745-757. Medline

Carnevale NT, Hines ML (2006) The neuron book. Cambridge, UK: Cambridge University.

Carter AG, Regehr WG (2002) Quantal events shape cerebellar interneuron firing. Nat Neurosci 5:1309-1318. CrossRef Medline

Cesana E, Pietrajtis K, Bidoret C, Isope P, D’Angelo E, Dieudonné S, Forti L (2013) Granule cell ascending axon excitatory synapses onto Golgi cells implement a potent feedback circuit in the cerebellar granular layer. J Neurosci 33:12430-12446. CrossRef Medline

Chadderton P, Margrie TW, Häusser M (2004) Integration of quanta in cerebellar granule cells during sensory processing. Nature 428:856-860. CrossRef Medline

Crowley JJ, Fioravante D, Regehr WG (2009) Dynamics of fast and slow inhibition from cerebellar golgi cells allow flexible control of synaptic integration. Neuron 63:843-853. CrossRef Medline

D'Angelo E, De Zeeuw CI (2009) Timing and plasticity in the cerebellum: focus on the granular layer. Trends Neurosci 32:30-40. CrossRef Medline

Dieudonné S (1998) Submillisecond kinetics and low efficacy of parallel fibre-Golgi cell synaptic currents in the rat cerebellum. J Physiol 510:845866. CrossRef Medline

Dugué GP, Dumoulin A, Triller A, Dieudonné S (2005) Target-dependent use of co-released inhibitory transmitters at central synapses. J Neurosci 25:6490-6498. CrossRef Medline

Dugué GP, Brunel N, Hakim V, Schwartz E, Chat M, Lévesque M, Courtemanche R, Lena C, Dieudonné S (2009) Electrical coupling mediates tunable low-frequency oscillations and resonance in the cerebellar Golgi cell network. Neuron 61:126-139. CrossRef Medline

Duguid I, Branco T, London M, Chadderton P, Häusser M (2012) Tonic inhibition enhances fidelity of sensory information transmission in the cerebellar cortex. J Neurosci 32:11132-11143. CrossRef Medline

Eccles JC, Ito M, Szentagothai J (1967) The cerebellum as a neuronal machine. Berlin: Springer.

Ferragamo MJ, Golding NL, Gardner SM, Oertel D (1998) Golgi cells in the superficial granule cell domain overlying the ventral cochlear nucleus: morphology and electrophysiology in slices. J Comp Neurol 400:519528. Medline

Fünfschilling U, Reichardt LF (2002) Cre-mediated recombination in rhombic lip derivatives. Genesis 33:160-169. CrossRef Medline

Galliano E, Baratella M, Sgritta M, Ruigrok TJ, Haasdijk ED, Hoebeek FE, D’Angelo E, Jaarsma D, De Zeeuw CI (2013a) Anatomical investigation of potential contacts between climbing fibers and cerebellar Golgi cells in the mouse. Front Neural Circuits 7:59. CrossRef Medline

Galliano E, Gao Z, Schonewille M, Todorov B, Simons E, Pop AS, D’Angelo E, van den Maagdenberg AM, Hoebeek FE, De Zeeuw CI (2013b) Silencing the majority of cerebellar granule cells uncovers their essential role in motor learning and consolidation. Cell Rep 3:1239-1251. CrossRef Medline

Gardner SM, Trussell LO, Oertel D (1999) Time course and permeation of synaptic AMPA receptors in cochlear nuclear neurons correlate with input. J Neurosci 19:8721-8729. Medline

Gardner SM, Trussell LO, Oertel D (2001) Correlation of AMPA receptor subunit composition with synaptic input in the mammalian cochlear nuclei. J Neurosci 21:7428-7437. Medline

Hamann M, Rossi DJ, Attwell D (2002) Tonic and spillover inhibition of 
granule cells control information flow through cerebellar cortex. Neuron 33:625-633. CrossRef Medline

Irie T, Fukui I, Ohmori H (2006) Activation of GIRK channels by muscarinic receptors and group II metabotropic glutamate receptors suppresses Golgi cell activity in the cochlear nucleus of mice. J Neurophysiol 96: 2633-2644. CrossRef Medline

Isope P, Barbour B (2002) Properties of unitary granule cell->Purkinje cell synapses in adult rat cerebellar slices. J Neurosci 22:9668-9678. Medline

Jaarsma D, Diño MR, Ohishi H, Shigemoto R, Mugnaini E (1998) Metabotropic glutamate receptors are associated with non-synaptic appendages of unipolar brush cells in rat cerebellar cortex and cochlear nuclear complex. J Neurocytol 27:303-327. CrossRef Medline

Jakab RL, Hámori J (1988) Quantitative morphology and synaptology of cerebellar glomeruli in the rat. Anat Embryol (Berl) 179:81-88. CrossRef Medline

Jörntell H, Ekerot CF (2006) Properties of somatosensory synaptic integration in cerebellar granule cells in vivo. J Neurosci 26:11786-11797. CrossRef Medline

Kanichay RT, Silver RA (2008) Synaptic and cellular properties of the feedforward inhibitory circuit within the input layer of the cerebellar cortex. J Neurosci 28:8955-8967. CrossRef Medline

Kennedy A, Wayne G, Kaifosh P, Alviña K, Abbott LF, Sawtell NB (2014) A temporal basis for predicting the sensory consequences of motor commands in an electric fish. Nat Neurosci 17:416-422. CrossRef Medline

Levy RB, Reyes AD (2012) Spatial profile of excitatory and inhibitory synaptic connectivity in mouse primary auditory cortex. J Neurosci 32:56095619. CrossRef Medline

Liu A, Regehr WG (2014) Normalization of input patterns in an associative network. J Neurophysiol 111:544-551. CrossRef Medline

Liu SJ, Cull-Candy SG (2002) Activity-dependent change in AMPA receptor properties in cerebellar stellate cells. J Neurosci 22:3881-3889. Medline

Loewenstein Y, Mahon S, Chadderton P, Kitamura K, Sompolinsky H, Yarom Y, Häusser M (2005) Bistability of cerebellar Purkinje cells modulated by sensory stimulation. Nat Neurosci 8:202-211. CrossRef Medline

Madisen L, Zwingman TA, Sunkin SM, Oh SW, Zariwala HA, Gu H, Ng LL, Palmiter RD, Hawrylycz MJ, Jones AR, Lein ES, Zeng H (2010) A robust and high-throughput Cre reporting and characterization system for the whole mouse brain. Nat Neurosci 13:133-140. CrossRef Medline

Mapelli J, D'Angelo E (2007) The spatial organization of long-term synaptic plasticity at the input stage of cerebellum. J Neurosci 27:1285-1296. CrossRef Medline

Marr D (1969) A theory of cerebellar cortex. J Physiol 202:437-470. CrossRef Medline

Menuz K, O’Brien JL, Karmizadegan S, Bredt DS, Nicoll RA (2008) TARP redundancy is critical for maintaining AMPA receptor function. J Neurosci 28:8740-8746. CrossRef Medline

Mitchell SJ, Silver RA (2000) Glutamate spillover suppresses inhibition by activating presynaptic mGluRs. Nature 404:498-502. CrossRef Medline

Mitchell SJ, Silver RA (2003) Shunting inhibition modulates neuronal gain during synaptic excitation. Neuron 38:433-445. CrossRef Medline

Mugnaini E, Osen KK, Dahl AL, Friedrich VL Jr, Korte G (1980) Fine structure of granule cells and related interneurons (termed Golgi cells) in the cochlear nuclear complex of cat, rat, and mouse. J Neurocytol 9:537-570. CrossRef Medline

Oertel D, Young ED (2004) What's a cerebellar circuit doing in the auditory system? Trends Neurosci 27:104-110. CrossRef Medline

Paternain AV, Morales M, Lerma J (1995) Selective antagonism of AMPA receptors unmasks kainate receptor-mediated responses in hippocampal neurons. Neuron 14:185-189. CrossRef Medline

Prsa M, Dash S, Catz N, Dicke PW, Thier P (2009) Characteristics of responses of Golgi cells and mossy fibers to eye saccades and saccadic adaptation recorded from the posterior vermis of the cerebellum. J Neurosci 29:250-262. CrossRef Medline

Rancz EA, Ishikawa T, Duguid I, Chadderton P, Mahon S, Häusser M (2007) High-fidelity transmission of sensory information by single cerebellar mossy fibre boutons. Nature 450:1245-1248. CrossRef Medline

Rieubland S, Roth A, Häusser M (2014) Structured connectivity in cerebellar inhibitory networks. Neuron 81:913-929. CrossRef Medline
Ritzau-Jost A, Delvendahl I, Rings A, Byczkowicz N, Harada H, Shigemoto R, Hirrlinger J, Eilers J, Hallermann S (2014) Ultrafast action potentials mediate kilohertz signaling at a central synapse. Neuron 84:152-163. CrossRef Medline

Roberts MT, Trussell LO (2010) Molecular layer inhibitory interneurons provide feedforward and lateral inhibition in the dorsal cochlear nucleus. J Neurophysiol 104:2462-2473. CrossRef Medline

Rossi DJ, Hamann M (1998) Spillover-mediated transmission at inhibitory synapses promoted by high affinity alpha6 subunit $\mathrm{GABA}(\mathrm{A})$ receptors and glomerular geometry. Neuron 20:783-795. CrossRef Medline

Rossi DJ, Hamann M, Attwell D (2003) Multiple modes of GABAergic inhibition of rat cerebellar granule cells. J Physiol 548:97-110. CrossRef Medline

Rothman JS, Silver RA (2014) Data-driven modeling of synaptic transmission and integration. Prog Mol Biol Transl Sci 123:305-350. CrossRef Medline

Rothman JS, Cathala L, Steuber V, Silver RA (2009) Synaptic depression enables neuronal gain control. Nature 457:1015-1018. CrossRef Medline

Rousseau CV, Dugué GP, Dumoulin A, Mugnaini E, Dieudonné S, Diana MA (2012) Mixed inhibitory synaptic balance correlates with glutamatergic synaptic phenotype in cerebellar unipolar brush cells. J Neurosci 32:46324644. CrossRef Medline

Ruigrok TJ, Hensbroek RA, Simpson JI (2011) Spontaneous activity signatures of morphologically identified interneurons in the vestibulocerebellum. J Neurosci 31:712-724. CrossRef Medline

Russo MJ, Mugnaini E, Martina M (2007) Intrinsic properties and mechanisms of spontaneous firing in mouse cerebellar unipolar brush cells. J Physiol 581:709-724. CrossRef Medline

Satake S, Imoto K (2014) Cav2.1 channels control multivesicular release by relying on their distance from exocytotic $\mathrm{Ca} 2+$ sensors at rat cerebellar granule cells. J Neurosci 34:1462-1474. CrossRef Medline

Sawtell NB (2010) Multimodal integration in granule cells as a basis for associative plasticity and sensory prediction in a cerebellum-like circuit. Neuron 66:573-584. CrossRef Medline

Schwartz EJ, Rothman JS, Dugué GP, Diana M, Rousseau C, Silver RA, Dieudonné S (2012) NMDA receptors with incomplete $\mathrm{Mg}^{2+}$ block enable low-frequency transmission through the cerebellar cortex. J Neurosci 32:6878-6893. CrossRef Medline

Simões de Souza FM, De Schutter E (2011) Robustness effect of gap junctions between Golgi cells on cerebellar cortex oscillations. Neural Syst Circuits 1:7. CrossRef Medline

Solinas S, Forti L, Cesana E, Mapelli J, De Schutter E, D’Angelo E (2007) Computational reconstruction of pacemaking and intrinsic electroresponsiveness in cerebellar Golgi cells. Front Cell Neurosci 1:2. Medline

van Kan PL, Gibson AR, Houk JC (1993) Movement-related inputs to intermediate cerebellum of the monkey. J Neurophysiol 69:74-94. Medline

Varela JA, Sen K, Gibson J, Fost J, Abbott LF, Nelson SB (1997) A quantitative description of short-term plasticity at excitatory synapses in layer $2 / 3$ of rat primary visual cortex. J Neurosci 17:7926-7940. Medline

Vervaeke K, Lorincz A, Nusser Z, Silver RA (2012) Gap junctions compensate for sublinear dendritic integration in an inhibitory network. Science 335:1624-1628. CrossRef Medline

Watanabe D, Nakanishi S (2003) mGluR2 postsynaptically senses granule cell inputs at Golgi cell synapses. Neuron 39:821-829. CrossRef Medline

Watanabe D, Inokawa H, Hashimoto K, Suzuki N, Kano M, Shigemoto R, Hirano T, Toyama K, Kaneko S, Yokoi M, Moriyoshi K, Suzuki M, Kobayashi K, Nagatsu T, Kreitman RJ, Pastan I, Nakanishi S (1998) Ablation of cerebellar Golgi cells disrupts synaptic integration involving GABA inhibition and NMDA receptor activation in motor coordination. Cell 95:17-27. CrossRef Medline

Xu W, Edgley SA (2008) Climbing fibre-dependent changes in Golgi cell responses to peripheral stimulation. J Physiol 586:4951-4959. CrossRef Medline

Zhang J, Han VZ, Meek J, Bell CC (2007) Granular cells of the mormyrid electrosensory lobe and postsynaptic control over presynaptic spike occurrence and amplitude through an electrical synapse. J Neurophysiol 97:2191-2203. CrossRef Medline

Zucker RS, Regehr WG (2002) Short-term synaptic plasticity. Annu Rev Physiol 64:355-405. CrossRef Medline 